\title{
Advice issued by professional homeopathic associations: a survey of websites
}

The debate about the value of homeopathy is as old as homeopathy itself. ${ }^{1}$ Recently, it has reached new heights when 'the end of homeopathy' was proclaimed by a leading medical journal. ${ }^{2}$ A central issue in this debate obviously is the scientific proof of efficacy of homeopathic medicines. ${ }^{3}$ Homeopaths tend to either claim that conventional science does not provide the tools for evaluating homeopathy, ${ }^{4}$ or that much of the clinical trial data are demonstrably positive. ${ }^{5}$ Yet independent systematic reviews of rigorous studies regularly fail to confirm this notion. ${ }^{6}$
In this context, it is relevant to evaluate the contents of the websites of professional associations of homeopaths. This was the purpose of the present survey. In particular, my aim was to monitor what therapeutic claims are being published.

\section{METHOD}

The websites of all professional homeopathic associations were visited (date 5 August 2008). Those using languages other than English, French, or German were excluded. All sites were searched for statements on the effectiveness of homeopathy for specific medical conditions. Subsequently, this information was extracted into a table (Table 1).

\section{RESULTS}

Thirty associations' websites were located of which eight were excluded because of the language restrictions mentioned above. Of the remaining 22 sites, 12 published statements about the effectiveness of homeopathy for specific medical conditions (Table 1). ${ }^{7-17}$

These data show that about half of all

Table 1. Statements from websites.

\begin{tabular}{|c|c|c|}
\hline Organisation & Statement & Comment \\
\hline $\begin{array}{l}\text { British Association of Homeopathic } \\
\text { Veterinary Surgeons }\end{array}$ & $\begin{array}{l}\text { Dozens of claims; five examples: aconitum treats shock, belladonna for } \\
\text { high fevers, colocynthis for colic in horses, hamamelis for bleeding } \\
\text { from wounds, hepar sulph for septic infections }\end{array}$ & $\begin{array}{l}\text { Under the heading of 'Homeopathic } \\
\text { first-aid medicines' }\end{array}$ \\
\hline British Homeopathic Association & $\begin{array}{l}\text { 'Many conditions can be treated effectively by homeopathy, from asthma, } \\
\text { rheumatism, arthritis, eczema to ... cuts and bruises' }\end{array}$ & $\begin{array}{l}\text { Extracted from the FAQ section } \\
\text { of the site }\end{array}$ \\
\hline $\begin{array}{l}\text { British Homeopathic Dental } \\
\text { Association }\end{array}$ & $\begin{array}{l}\text { 'There are remedies which stop swelling ... reduce pain ... cure ulcers } \\
\text { and cold sores and many more' }\end{array}$ & $\begin{array}{l}\text { Extracted from 'Why should you } \\
\text { visit a homeopathic dentist?' }\end{array}$ \\
\hline Faculty of Homeopathy Malaysia & $\begin{array}{l}\text { 'Migraine, gastric, stroke, diabetes, hypertension, cancer, fibroid, renal } \\
\text { failure, brain tumour, blood clot, hepatitis, gout, arthritis, low sperm count, } \\
\text { impotence, stammering, tonsilitis, infertility, and children diseases' }\end{array}$ & $\begin{array}{l}\text { Under the heading 'Diseases that } \\
\text { respond well with homeopathy' }\end{array}$ \\
\hline $\begin{array}{l}\text { Ősterreichische Gesellschaft für } \\
\text { Homöopathie (Austria) }\end{array}$ & $\begin{array}{l}\text { Dozens of claims; five examples: aconite for infections, arsenicum album } \\
\text { for burning pain in stomach, belladonna for flu, cantharis for bloody urine, } \\
\text { hepar sulfuris for infected skin lesions }\end{array}$ & $\begin{array}{l}\text { Under the heading 'Homeopathic } \\
\text { medicine cabinet' (my translation) }\end{array}$ \\
\hline $\begin{array}{l}\text { Homeopathic Medical Association } \\
\text { (UK) }\end{array}$ & $\begin{array}{l}\text { 'Cuts, bruises, minor burns, insect bites, hangovers, etcetera. Also extremely } \\
\text { effective for allergies, depression, phobias and much, much more' }\end{array}$ & $\begin{array}{l}\text { From 'What can it be used for?'. The } \\
\text { site also contains a section entitled } \\
\text { 'Immunisation' which implies that } \\
\text { homeopathy is preferable to } \\
\text { immunisations }\end{array}$ \\
\hline $\begin{array}{l}\text { Homeopathic Medical Association } \\
\text { of Canada }\end{array}$ & 'Homeopathy helps for winter vomiting bug' & $\begin{array}{l}\text { Extracted from a press release } \\
\text { dated } 14 \text { Feb } 2008\end{array}$ \\
\hline Irish Society of Homeopaths & Addiction, allergies & Under the heading 'Testimonials' \\
\hline $\begin{array}{l}\text { National Center for Homeopathy } \\
\text { (US) }\end{array}$ & 'Find out recommended remedies for this year's flu ...' & $\begin{array}{l}\text { Under the heading 'Help in epidemics } \\
\text { and crises' }\end{array}$ \\
\hline New Zealand Homeopathic Society & $\begin{array}{l}\text { Dozens of claims; five examples: memory loss, vaginitis, labour injuries, } \\
\text { asthma, croup }\end{array}$ & $\begin{array}{l}\text { Under the heading 'What can } \\
\text { homeopathy treat?' }\end{array}$ \\
\hline The Society of Homeopaths (UK) & $\begin{array}{l}\text { Acute fevers, sore throats, toothache, arthritis, eczema, asthma, } \\
\text { anxiety, insomnia }\end{array}$ & $\begin{array}{l}\text { Under the heading 'What can } \\
\text { homeopathy treat?' }\end{array}$ \\
\hline $\begin{array}{l}\text { Verband Klassischer Homöopathen } \\
\text { Deutschlands (Germany) }\end{array}$ & $\begin{array}{l}\text { Acute bacterial and viral infections, allergies, migraine, chronic pain, } \\
\text { proneness to infections, diseases of the musculoskeletal system, } \\
\text { psychosomatic problems }\end{array}$ & (my translation) \\
\hline
\end{tabular}


homeopathic associations recommend homeopathic treatments for a wide range of conditions some of which are serious, even life-threatening. There seems to be little agreement between these recommendations.

\section{DISCUSSION}

According to this survey, many professional homeopathic associations provide rather concrete recommendations evidently aimed at the lay public. Frequently mentioned indications include asthma, eczema, and infections.

It is relevant to contrast these recommendations with the evidence from controlled clinical trials. A Cochrane review entitled 'Homeopathy for asthma' found six such studies with a total of 556 patients. Its authors concluded that 'there is not enough evidence to reliably assess the possible role of homeopathy in asthma'. ${ }^{18}$ No data from controlled clinical trials seem to exist for eczema. ${ }^{19}$ In the case of infections, a Cochrane review is available of homeopathic oscillococcinum for preventing and treating influenza and influenza-like syndromes. Its authors conclude that, 'although promising, the data were not strong enough to make a general recommendation ...20 For other types of infections, for example, hepatitis, herpes simplex, herpes zoster, or upper respiratory infections, there are either no or no convincing trial data. ${ }^{21}$ As to the other conditions mentioned in Table 1 , compelling evidence from clinical trials is also lacking. ${ }^{21}$

Homeopaths might argue that the clinical trial is not an adequate method for establishing the value of homeopathy. ${ }^{4} \mathrm{~A}$ full discussion of this question would be beyond the scope of this article; but even if we accepted this notion to be true, one would have to insist that this is made clear to the readers of the websites in question. One could, for instance, include a disclaimer stating that none of these statements is supported by evidence from controlled clinical trials.

Therefore, it seems to follow that the recommendations by professional homeopathic associations are not based on the evidence from controlled clinical trials. As they are, at least in some cases, related to potentially serious conditions, this advice does not seem responsible. It may therefore be hardly surprising that, in the UK, more and more NHS trusts reject homeopathy. ${ }^{22}$

\section{Edzard Ernst}

\section{REFERENCES}

1. Ernst E. The heresy of homoeopathy: a brief history of 200 years of criticism. Br Homeopath J 1998; 87: $28-32$.

2. Anonymous. The end of homoeopathy. Lancet 2005; 366(9487): 690 .

3. Gold PW, Novella S, Roy R, et al. Homeopathy quackery or a key to the future of medicine? Homeopathy 2008; 97: 28-33.

4. Milgrom LR. Journeys in the country of the blind: entanglement theory and the effects of blinding on trials of homeopathy and homeopathic provings. eCAM 2007; 4(1): 7-16.

5. Mathie RT. The research base for homeopathy: a fresh assessment of the literature. Homeopathy 2003; 92(2): 84-91.

6. Ernst E. A systematic review of systematic reviews of homeopathy. Br J Clin Pharmacol 2002; 54: 577-582.

7. British Association of Homeopathic Veterinary Surgeons. Homeopathy works.

http://www.bahvs.com/first-aid.htm (accessed 9 Jan 2009).

8. British Homeopathic Association Incorporating the Homeopathic Trust. FAQS www.trusthomeopathy.org/trust/tru_faq.htm (accessed 9 Jan 2009).

9. British Homeopathic Dental Association. Why should you visit a homeopathic dentist? http://www.bhda.co.uk/why.php (accessed 9 Jan 2009)

10. Faculty of Homeopathy Malaysia. Why homoepathy? http://www.persatuanmrhp.freehomepage.com/whats new.html (accessed 9 Jan 2009).

11. Ostereichische Gesellschaft für Homöopathie. Homoeopathie. [Austrian Society for Homeopathy. Homeopathy]. http://www.homoeopathie.at/ (accessed 9 Jan 2009).

12. Homeopathic Medical Association - UK. Frequently Asked Questions. http://www.the-hma.org/faq.asp (accessed 9 Jan 2009)

13. Irish Society of Homeopaths. Testimonials http://www.irishhomeopathy.ie/index.php?option=co m_content\&task $=$ view\&id $=43 \& I t e m i d=66$ (accessed 9 Jan 2009).

14. National Center for Homeopathy. Help in epidemics and crises.

http://nationalcenterforhomeopathy.org/services/cris es/index.jsp (accessed 9 Jan 2009)

15. New Zealand Homoeopathic Society. What can homoeopathy treat?

http://www.homeopathy.ac.nz/general/frequentlyasked-questions/(accessed 9 Jan 2009).

16. The Society of Homeopaths. What can homeopathy treat? http://www.homeopathysoh.org/about\%2Dhomeopathy/ (accessed 9 Jan 2009).

17. Verband klassischer Homoeopathen Deutschlands. [Association of Classical Homeopaths of Germany]. http://www.vkhd.de/index.php?option=com content \&task $=$ view\&id $=15 \&$ Itemid $=41$ (accessed 9 Jan 2009)

18. McCarney RW, Linde K, Lasserson TJ. Homeopathy for chronic asthma. Cochrane Database Syst Rev 2004, 1: CD000353.

19. Kiel T, Witt CM, Roll S, et al. Homoeopathic versus conventional treatment of children with eczema: a comparative cohort study. Complement Ther Med 2008; 16: 15-21.

20. Vickers AJ, Smith C. Homeopathic oscillococcinum for preventing and treating influenza and influenzalike syndromes. Cochrane Database Syst Rev 2006; 3: CD001957.

21. Ernst E, Pittler MH, Wider B, Boddy K. The desktop guide to complementary and alternative medicine. 2nd edn. Edinburgh: Mosby/Elsevier, 2006.

22. BBC News. NHS trusts 'reject homeopathy'. http://news.bbc.co.uk/1/hi/health/7215470.stm (accessed 13 Jan 2009).

DOI: 10.3399/bjgp09X407036 